\title{
The Best Way to Unblock the Pipeline in CS is by Getting Everyone to Code in Schools. A Debate.
}

\author{
Annemieke Craig \\ Deakin University \\ Victoria \\ Australia \\ $+61352272152$ \\ a.craig@deakin.edu.au
}

\author{
Catherine Lang \\ La Trobe University \\ Victoria \\ Australia \\ $+61394791858$ \\ c.lang@latrobe.edu.au
}

\author{
MaryAnne Egan \\ Siena College \\ New York \\ United States \\ 1+518-782-6546 \\ maegan@siena.edu
}

\author{
Reyyan Ayfer \\ Bilkent University \\ Ankara \\ Turkey \\ +903122905065 \\ ayfer@bilkent.edu.tr
}

\begin{abstract}
Many believe that the push to increase the number of skilled computer scientists must be a multi-pronged approach and be institutionalized at all levels of education. Some federal and local governments are requiring that all students become proficient in technical areas in primary and secondary schooling. Will the call for all schools to teach every student coding be the magic bullet that unblocks the computing pipeline? Is adding another core subject to an already crowded curricula the answer? Are schools ready? It is noted that there is no universal computer science/coding curriculum for teachers to follow, some teachers don't have the skills or the enthusiasm to do this, not all students can think logically so why try to force them? In the words of Einstein "Everybody is a genius. But if you judge a fish by its ability to climb a tree, it will live its whole life believing that it is stupid".
\end{abstract}

\section{Keywords}

Gender diversity; computing curricula; teacher technical selfefficacy

\section{Debate Facilitator}

Barbara Boucher Owens, Ph.D., Southwestern University

\section{Speakers For:}

Dr Annemieke Craig is an Associate Professor in the Business School at Deakin University. Annemieke researches in the field of Information Systems with particular emphasis on trying to increase the involvement and representation of women in the computing professions. Annemieke has contributed to building the Women in Computing community, nationally and internationally.

Permission to make digital or hard copies of part or all of this work for personal or classroom use is granted without fee provided that copies are not made or distributed for profit or commercial advantage and that copies bear this notice and the full citation on the first page. Copyrights for third-party components of this work must be honored. For all other uses, contact the Owner/Author.

Copyright is held by the owner/author(s).

ITiCSE '16, July 09-13, 2016, Arequipa, Peru

ACM 978-1-4503-4231-5/16/07.

http://dx.doi.org/10.1145/2899415.2899418
On an international scale Annemieke was a council member of ACM-W, the Australian Ambassador for the ACM's Committee for Women and then led the ambassador program. She has chaired the Global Advisory Committee for two Grace Hopper Conferences as well as organising international panels at three Grace Hopper Conferences. Annemieke has been on the organising committee for the Go Girl- Go for IT program and a chief investigator in the ARC Funded research project Digital Divas.

Dr MaryAnne Egan is a Professor of Computer Science at Siena College. MaryAnne is involved in various aspects of computer science education including the recruitment and retention of underrepresented groups. In addition to presenting on these topics, she is co-PI on an NSF IUSE grant and regularly participates on the conference committees for Grace Hopper Celebration of Women in Computing, SIGCSE, ACM's Conference for Innovation and Technology in Computer Science Education (ITiCSE), Consortium for Computing Sciences in Colleges - Northeastern Region (CCSCNE) and NYCWiC. She is a member of the international Association of Computing Machinery Committee on Women in Computing, co-founder of the regional New York Celebration of Women in Computing (NYCWiC), and an active member of ACM Special Interest Group for Computer Science Education (SIGCSE).

\section{For argument:}

Some of the points that will be addressed by the FOR speakers include but are not limited to:

- Currently, many students are not exposed to coding, so they are unsure about careers in the field.

- If coding is compulsory, underrepresented groups in lower socio-economic schools would have access to the classes that are typically offered in the more affluent schools.

- Students who want to code now need to pay for lessons or seek out these schools.

- There will be 1.4 million new jobs created in the future in computing [1] and we aren't producing enough graduates to fill these jobs [2]

- We are currently missing large groups of young people who could help to mitigate the deficit of qualified tech employees

- While there may be a lack of teacher skills this is not insurmountable - students can turn to each other-- which could further encourage some students to not only work in CS, but possibly teach.

- Currently there is insufficient exposure at school to computational/algorithmic thinking - coding is a necessary 
way for students to understand the concepts of data, information and knowledge. Once students develop these computational skills, the idea of a major or career in CS is less daunting.

- $\quad$ Getting everyone to code in school takes away the stigma that is often associated with students who take CS classes in high school and eventually, computer scientists, in general.

- Students who go on to study other majors can take the knowledge learned in CS to enhance other career areas. Our world is much more interdisciplinary and most careers require some kind of technical knowledge. So, not only could we unblock the pipeline, we could even expand it!

\section{Speakers Against:}

Dr Catherine Lang is an Associate Professor in the School of Education, La Trobe University. Her research focus since 1996 has been on the under-representation of women in computing, which resulted in an Australian Research Council grant "Digital Divas" developing a curriculum based initiative for secondary school girls. She has published on the topics of student transition to higher education, computing education and pedagogy, as well as social networking in education. She was a founding board member of the Victorian ICT for Women Network, the ACM-W Australian Ambassador from 2005-2011 and the International Committee Liaison for the ACM's Special Interest Group for Computer Science Education (SIGCSE) for 2012 and 2013. She was the recipient of several competitive national and university grant and awards in recognition of her research strengths including Google CS4HS grants in 2013, 2014 and 2015.

Reyyan Ayfer decided to pursue a role in the field of education. after working for various organizations as a computer engineer for more than a decade and noting the increasing demand for expertise in programming, In 1988 she began working at Bilkent University in Ankara, Turkey and held a multitude of titles including: Department Chair of Computer Technology and Programming and Vice Chair of Computer and Instructional Technology Teacher Education where she also teaches, and the Director of the Institutional Relations and History Unit and Coordinator of BETS Bilkent Educational Technology Services. She also contributes her time to international committees, most notably as a council member of ACM Europe and as the Chair of ACM Women in Computing Europe Committee as well as leading a community of students who have formed the first international ACM-W Student Chapter.

\section{Against Argument:}

The against team will present a position that questions both the merit and feasibility of this proposal before questioning the effectiveness of compulsory computer science subjects in schools to unblock the pipeline.

The against argument will address, but are not limited to these points:

- There are many disciplines competing for space in the curriculum in schools. Education is a very competitive field - unfortunately it is driven by politics [3].
- Currently the political conversations are around STEM [with or without the A for Arts] Consider each of these subjects. Science is core in most curricula to Year 10. Technology is used in schools, 1:1 devices are the norm in western nations. Engineering is about creativity and hands on activities in the tech block and in most schools Maths is core to Year 10 [4].

- $\quad$ These disciplines also lack diversity and popularity despite being compulsory in the curriculum. Compulsory subjects do not create desire for further education in the discipline.

- The issue is not a lack of awareness of computer science. The issue is who influences students in their course and career choices: parents, teachers $[5,6]$.

- The issue is also the schizophrenic nature of the discipline computer science, information systems, information technology, media computation.

- The issue is the continued gender stereotypes and poor behaviors that get much media - young pale males, brogrammers, ageist, sexist, racist $[7,8]$

- Introducing compulsory coding will have a minimal influence on parents and may turn teachers away too - The two major course and career choice influencers.

\section{References}

[1] Department of Labor Bureau of Labor, Employment by Detailed Occupation 2014 (Occupational Category: 151100)

[2] New York Times: De Blasio to Announce 10-Year Deadline to Offer Computer Science to All Students, 9/15/15.

(http://www.nytimes.com/2015/09/16/nyregion/deblasio-to-announce-10-year-deadline-to-offercomputer-science-to-all-students.html )

[3] Teacher Magazine Stem Subjects Open Up Diverse Career Paths 5 April 2016 https://www.teachermagazine.com.au/article/stemsubjects-open-up-diverse-career-paths

[4] Report: Australia's STEM Workforce http://www.chiefscientist.gov.au/2016/03/reportaustralias-stem-workforce/ March 2016

[5] Lang, C. (2010). Happenstance and Compromise: a gendered analysis of students computing degree course selection. Computer Science Education, 20(4), 317-345.

[6] Lang, C. (2012). Sequential Attrition of Secondary School Student Interest in IT Courses and Careers. Information Technology and People, 25(3), 281-299.

[7] Lyons, D. Congratulations! You've been fired. April 92016 http://www.nytimes.com/2016/04/10/opinion/sunday/c ongratulations-youve-been-fired.html? $\mathrm{r}=0$

[8] Wong, A. The Australian tech industry will only close the skills gap if it addresses diversity. 26 April 2016 http://www.startupsmart.com.au/advice/growth/theaustralia-it-industry-will-only-close-the-skills-gapwhen-it-addresses-diversity/ 